\title{
Effects of Supplementation with Beef or Whey Protein Versus Carbohydrate in Master
}

\section{Triathletes}

\section{Authors}

Fernando Naclerio $^{1}, \mathrm{PhD}$, Marco Seijo ${ }^{1}, \mathrm{PhD}$, Eneko Larumbe-Zabala ${ }^{2}, \mathrm{PhD}$, Nadia Ashrafi ${ }^{1}, \mathrm{PhD}$, Tatiana Christides ${ }^{1}, \mathrm{PhD}$, Bettina Karsten ${ }^{1}, \mathrm{PhD}$, Birthe V. Nielsen ${ }^{1} \mathrm{PhD}$.

${ }^{1}$ Department of Life and Sport Science, Faculty of Engineering and Science, University of Greenwich, United Kingdom

${ }^{2}$ Clinical Research Institute, Texas Tech University Health Sciences Center, Lubbock, TX, USA

\section{Corresponding Author:}

Fernando Naclerio, Ph D. University of Greenwich, Medway Campus, Central Avenue, Chatham Maritime, Kent ME4 4TB. Tel: +44(0) 20831 8441Fax: +44(0) 208319805

E-mail: f.j.naclerio@gre.ac.uk

Running Title: Protein Supplementation in Master Triathletes Journal of the American College of Nutrition, accepted on 22/05/2017 DOI: $10.1080 / 07315724.2017 .1335248$ 


\begin{abstract}
Objective: The present study compares the effect of ingesting hydrolyzed beef protein, whey protein, and carbohydrate on performance, body composition (via plethysmography), muscular thickness, and blood indices of health, including ferritin concentrations, following a 10 -week intervention program.
\end{abstract}

Methods: After being randomly assigned to one of the following groups: Beef, Whey, or Carbohydrate, twenty four master-age male triathletes ( $n=8$ per treatment) ingested $20 \mathrm{~g}$ of supplement, mixed with plain water once a day (immediately after training or before breakfast). All measurements were performed pre and post interventions.

Results: Only Beef significantly reduced body mass $(\mathrm{p}=0.021)$ along with a trend to preserve or increase thigh muscle mass $(34.1 \pm 6.1 \mathrm{vs} 35.5 \pm 7.4 \mathrm{~mm})$. Both Whey $(38.4 \pm 3.8 \mathrm{vs} 36.9 \pm 2.8 \mathrm{~mm})$ and Carbohydrate $(36.0 \pm 4.8$ vs $34.1 \pm 4.4 \mathrm{~mm})$ interventions demonstrated a significantly $(\mathrm{p}<0.05)$ decreased vastus medialis thickness Additionally; The Beef condition produced a significant $(\mathrm{p}<0.05)$ increase in ferritin concentrations $(117 \pm 78.3$ vs $150.5 \pm 82.8 \mathrm{ng} / \mathrm{mL})$. No such changes were observed for the Whey $(149.1 \pm 92.1$ vs $138.5 \pm 77.7 \mathrm{ng} / \mathrm{mL})$ and Carbohydrate $(149.0 \pm 41.3$ vs $150.0 \pm 48.1 \mathrm{ng} / \mathrm{mL}$ ) groups. Furthermore, ferritin changes in the Beef group were higher than the modification observed in Whey $(\mathrm{p}<0.001)$ and Carbohydrate $(\mathrm{p}=0.025)$. No differences were found between Whey and Carbohydrate conditions $(\mathrm{p}=0.223)$. No further changes were observed.

Conclusion: Ingesting a hydrolyzed beef protein beverage after workout or before breakfast (non training days) can be effective in preserving thigh muscle mass and in improving iron status in male master-age triathletes.

Keywords: endurance athletes, diet, iron, ferritin, meat, maltodextrin, muscle thickness 


\section{INTRODUCTION}

Endurance athletes have a higher tendency to develop both iron depletion and deficiency, which over time can cause anemia, and impair training capacities whilst demonstrating a reduction in performance [1]. The reasons for the elevated iron demand in endurance athletes are an increased turnover and a loss through foot strike hemolysis, sweat, and gastrointestinal bleeding [1, 2]. The rate of depletion of iron stores depends upon a balanced relationship between body iron loss, and heme iron (the organic form of iron derived from animals) and non-heme iron (the inorganic form of iron derived from vegetable and cereal) intake [3].

Even though the prevalence of iron depletion is higher in females than in males, current trends in reducing animal-based foods in favor of a higher proportion of vegetable sources could, however, also negatively impact the iron stores in males performing serious endurance training regimens [1]. This is because absorption of the non-heme iron derived from plant-based sources is inhibited by many dietary factors including phytates and polyphenols that are also abundantly present in plants-based foods; non-heme iron absorption ranges from $2-10 \%$ of intake. In contrast, heme-iron, present within hemoglobin or myoglobin molecules is highly bioavailable [4]. The absorption of heme-iron is affected by few dietary factors and its uptake can be as efficient as $40 \%$ [3]. However, heme-iron has been estimated to only provide about $10 \%$ of all dietary iron in endurance athletes [4]. Compared to plant-based derived non-heme iron, red meat is a rich source of heme-iron with a higher bioavailability [1]. Thus, dietary modification has been suggested as a preferred strategy for ensuring adequate iron intake, maintenance of iron status, and as the first line of action in the prevention of iron deficiency in athletes [4].

It is also well known that aerobic training diminishes amino acid utilization [5]. However, the oxidation capacity of amino acid augments as a result of an improved activity of the limiting enzyme, glutamate dehydrogenase [6]. For this reason, endurance athletes should increase their daily protein intake. Additionally, master endurance athletes who due to age-related anabolic resistance recover at a slower rate from training [7] should consume a higher doses of high-quality 
proteins administered throughout the day and immediately after training [5]. Indeed, different nutritional strategies, including the consumption of high quality protein sources providing elevated amount of micronutrients have been proposed as an effective nutritional countermeasure to optimize training adaptations, to hasten recovery processes, and to avoid training-related nutritional deficiencies after endurance training $[5,8]$.

Both whey and beef are high-quality protein sources with a very similar amino acid composition to that found in the skeletal muscle [9, 10]. Although whey contains higher concentrations of branched-chain amino acid (BCAA), specifically leucine, which is essential for supporting muscle protein synthesis after exercise [11], beef is also a source of iron, zinc, vitamin B12, and essential fatty acid [12]. Furthermore, it has been suggested that inflammation secondary to strenuous exercise leads to the release of hepcidin, a liver hormone that is a negative regulator of gut iron absorption. As hepcidin would interfere with non-heme iron absorption after strenuous exercise, the consumption of iron supplements in this period would not be effective [13]. Consequently high micronutrient density food would be the best approach for maximizing recovery and providing a convenient amount of nutrients during the post-workout time. It can therefore be hypothesized that the post-workout ingestion of a high-quality protein beverage with a high proportion of essential amino acids and high micronutrient density of vitamins B, zinc, and hemeiron will support recovery and prevent exercise-induced iron deficiency in endurance athletes. Therefore, interventions aiming to analyze training outcomes and hematological changes would be particularly relevant for endurance athletes. The aim of the current investigation therefore was to compare the effects of combining a 10-week endurance training program with one of the following commercially-available products: 1) beef hydrolyzed protein powder $\left(100 \%\right.$ All Beef, Crown ${ }^{\circledR}$ Sport Nutrition, Spain); 2) whey isolate (Isolac, Carbery); and 3) non-protein, carbohydrate-only (maltodextrin), on performance, body composition, muscular thickness, and blood indices of health, including markers of iron deficiency such as serum ferritin, in master-age endurance triathletes. 


\section{Participants}

Thirty male master triathletes met the requirements to participate in the present study. Key criteria for inclusion were: (a) 35-60 years of age; (b) pre study performance of regular endurance training for at least 2 years c) a normal health history; (d) free from musculoskeletal limitations; (e) agreement to not ingest any other nutritional supplements or non-prescription drugs/medication that can affect blood markers of health including ferritin or hematocrit, as well as muscle growth and the ability to train intensely during the study; (f) fluency in English. Key criteria used for exclusion were: (a) history of metabolic conditions and/or diseases; (b) use of a variety of medications including, but not limited to, those with androgenic and/or anabolic effects and/or nutritional supplements known to improve strength and/or muscle mass such as creatine, essential amino acids, whey protein, glutamine, dehydroepiandrosterone (DHEA), multi-vitamin or iron-supplement use within 8 weeks prior to the start of the study; (d) current use of tobacco products; (e) the presence of any soft tissue or orthopedic limitations. Compliance was confirmed verbally and prior to providing written consent, participants were informed of the potential risks and benefits of the investigation.

All experimental procedures were conducted in accordance with the Declaration of Helsinki, and approved by the University Research Ethics Committee. As summarized in Figure 1, after assessing for eligibility, 24 of the 30 recruited participants completed the study. The study was conducted during the winter and spring of 2016. Trial Registration: ClinicalTrials.gov, U.S. National Institutes of Health (Identifier: NCT02675348).

\section{Figure 1 about here}

\section{Experimental Design:}

The present study involved a double blind three parallel groups randomized controlled trial between-participant design. The participants were randomly allocated into three equal-size treatment groups: beef protein, $n=10$; whey protein, $n=10$; or carbohydrate only $(\mathrm{CHO}), \mathrm{n}=10$. Before and after a 10-week endurance training concomitant with either of the supplementary treatment period, measurements of body composition, vastus medialis muscle thickness, peak 
oxygen consumption $\left(\dot{V} \mathrm{O}_{2 \text { peak }}\right)$, blood cell $\left(10^{6} / \mathrm{mm}^{3}\right)$ hemoglobin concentration $(\mathrm{g} / \mathrm{dl})$, hematocrit (\%), mean corpuscular volume $\left(\mathrm{mm}^{3}\right)$, mean corpuscular hemoglobin mass (pg), mean corpuscular hemoglobin concentration $(\mathrm{g} / \mathrm{dl})$, red cell distribution width $(\%)$, and ferritin concentration $(\mathrm{ng} / \mathrm{mL})$ were determined. Following a pre-intervention endurance assessment, the participants were matched by their $\dot{V} \mathrm{O}_{2 \text { peak }}$ values, body composition, and age. In a double blind fashion, the assignment of participants to treatments was performed by block randomization using a block size of three. Presented as mean (SD) the initial groups characteristics were as follows: Beef: age $47.0(8.9)$ years, height $1.77(0.07) \mathrm{m}$, body mass $78.2(8.1) \mathrm{kg}, \dot{V} \mathrm{O}_{2 \text { peak }} 48.2$ (5.4) $\mathrm{ml} / \mathrm{kg} / \mathrm{min}^{-1}$; Whey: age 45.3 (8.9) years, height $1.79(0.05) \mathrm{m}$, body mass 80.6 (13.2) kg, $\dot{V} \mathrm{O}_{2 \text { peak }} 46.4$ (7.1) ml/kg/min ${ }^{-1}$; CHO: age 46.2 (7.0) years, height $1.81(0.05) \mathrm{m}$, body mass $77.9(7.5) \mathrm{kg} \dot{V} \mathrm{O}_{2 \text { peak }} 48.5$ (6.9) $\mathrm{ml} / \mathrm{kg} / \mathrm{min}^{-1}$.

\section{Dietary (Nutrition) Monitoring}

A qualified nutritionist collected dietary habits information of participants and explained the correct procedures for recording dietary intake. To determine energy and macronutrient content, each participant's baseline diet (3 days, 2 weekdays, and 1 weekend day) was analyzed using Dietplan 6 software. Participants were instructed to maintain their normal diet throughout the training period. In order to determine changes and evaluate differences caused by the supplementation protocol, diet composition was analyzed again during the last week of the intervention protocol.

\section{Measurements}

Body Composition: Body mass (BM) and height were assessed on a standard scale and stadiometer according the methods described by Ross and Marfel-Jones [14]. Whole body densitometry was assessed using air displacement via the Bod $\operatorname{Pod}^{\circledR}$ (Life Measurements, Concord, CA) in accordance with the manufacturer's instructions as detailed elsewhere [15]. Briefly, the participants were tested wearing only tight fitting clothing (swimsuit or undergarment) and an acrylic swim cap. Participants wore the exact same clothing for all testing. Thoracic gas volume was estimated using a predictive equation integral to the $\operatorname{Bod}^{\operatorname{Pod}^{\circledR}}$ software. The calculated value for 
body density was used in the Siri equation [16] to estimate body composition. Body composition measurements were performed twice. If the agreement on percentage of body fat was within $0.05 \%$, the two tests were averaged. If the two tests were outside the $0.05 \%$ agreement, a third test was performed and the average of the three measurements was used for all body composition variables.

Determination of Peak Oxygen Consumption $\left(\dot{\mathrm{V}}_{2 \text { peak }}\right)$ : Following a standardized warm-up, participants completed a progressive, incremental laboratory exercise test to exhaustion on a Cyclus2 ergometer (RBM Electronics, Leipzig, Germany). The test commenced at a work rate of 90 Watts. Thereafter, intensity increased at a step rate of 25 watts every minute. Participants were instructed to maintain a cadence between 70 and $80 \mathrm{rev} \mathrm{min}^{-1}$ throughout the test. When cadence dropped by more than $10 \mathrm{rev} \min ^{-1}$ for more than $10 \mathrm{~s}$ despite strong verbal encouragement, tests were terminated. Expired gases were collected continuously during the test using a Cortex MetaLyzer 3B gas analyzer (Cortex Biophysik, Leipzig, Germany). Additionally, heart rate (HR) was continuously monitored using a Polar Sporttester (Polar Electro, Finland). $\dot{V} \mathrm{O}_{2 \text { peak }}$ was calculated as the highest mean oxygen consumption over a 30-s period [17].

Muscle Thickness: Right-side vastus medialis muscle thicknesses were measured in real time using a Diasus diagnostic ultrasound-imaging unit (Dynamic Imaging, Livingston, UK) coupled to a $50 \mathrm{~mm}$ probe at a frequency of $7.5 \mathrm{MHZ}$. During measurements, participants were lying supine with the right knee in an extended position. The probe was placed perpendicular to the skin surface and bone tissues at a $80 \%$ distance between the lateral condyle and greater trochanter of the femur [18]. To provide acoustic contact without depressing the dermal surface, the probe was coated with a water-soluble transmission gel (Aquasonic 100 Ultrasound Transmission gel). Thickness was calculated as the distance between superficial and deep aponeuroses measured at the ends and middle region of each $3.8 \mathrm{~cm}$-wide sonograph.

Three images of each muscle were obtained for each point and the average of the results was calculated. To favor reproducibility, probe placement was carefully noted for reproduction during the next test sessions, and the same operator performed all the measurements. In order to avoid any 
swelling in the muscles that could interfere with the results, images were obtained at least 48 hours before and after any exercise intervention.

Blood Samples: After a fasting period of 8 hours, participants arrived at the physiology laboratory, on two separate occasions (one day before and one to two days after completion of the 10-week intervention period). Two vacutainer venous blood collection tubes (BD Vacutainer ${ }^{\circledR}$ Blood Collection Tubes) were used to collect $8 \mathrm{~mL}$ of venous blood from the antecubital vein. Containing EDTA as an anticoagulant, the first tube was inverted eight times and immediately analyzed for complete blood count, i.e., red blood cells (RBC) concentration, hemoglobin (HGB), hematocrit (HCT), mean corpuscular volume (MVC), mean corpuscular hemoglobin mass (MCH), mean corpuscular hemoglobin concentration (MCHC) and red cell distribution width (RDW), using a fully automated hematology analyzer (ABX Pentra 60C + , Horiba Medical, Montpellier, France). For the second tube (containing the additive silica to accelerate the clotting process), the serum was separated from clotted blood and used to determine serum ferritin concentrations. Before being centrifuged at $2400 \mathrm{rpm}$ for 10 minutes, the clot-activating tube was inverted five times and the whole blood was allowed to stand for about 50 minutes at room temperature to facilitate the clotting process. The resultant serum was aliquoted into labelled Eppendorf tubes and stored at $-80^{\circ} \mathrm{C}$.

According to the manufacturer, all reagents for the biochemical indicators of iron status $(1 \mathrm{x}$ diluent $\mathrm{M}, 1 \mathrm{x}$ wash buffer, $1 \mathrm{x}$ biotinylated ferritin detector antibody, 1x streptavidin-peroxidase conjugate for ferritin; $1 \mathrm{x}$ diluent $\mathrm{N})$ were equilibrated to room temperature $\left(18-25^{\circ} \mathrm{C}\right)$. The serum samples were diluted (1:10) with 1x Diluent $M$ for ferritin. Samples were analyzed in duplicates using ELISA (Abcam, UK) for ferritin concentrations analysis. The calibration curve was constructed of seven prepared ferritin standards $(0.7$ to $50 \mathrm{ng} / \mathrm{mL})$. Serum samples were interpolated at a wavelength of $450 \mathrm{~nm}$ from the calibration standards using a four-parameter logistic curve (My Assays, Version 2015). The mean intra assay coefficients of variation were $5.0 \%$ for ferritin. The mean inter assay coefficients of variation for ferritin was $8.4 \%$.

\section{Control of training}


All participants were competitive master triathletes and at the time of the study had consistently trained between 6 to 10 hours per week (four to seven training sessions per week) for the last three years.

During the progressive test, the values of heart rate (HR), Rate of Perceived Exertion (RPE) using a 15-point scale [20], the oxygen consumption corresponding to the first (VT1) a and second (VT2) ventilatory thresholds as well as the maximal heart rate (HRmax) were determined. Following the pre-screening, participants committed to follow a training intervention period consisted of a 10-week polarized endurance-training intensity distribution model. This model included three intensity zones delineated according to the VT2 localization and quantified using continuous heart rate registration and the associated RPE values determined during the progressive test. The polarized endurance-training intensity distribution model involves significant proportions of both high- and low-intensity training and only a small proportion of moderate-intensity training. The intensity zones were calculated as Zone 1 , low intensity: $\leq 75 \%$ of VT2, $\leq 72 \%$ of maximum heart rate (HRmax), rate of perceived exertion (RPE) 6 to 11; Zone 2, moderate intensity: between 76 and 95\% of VT2, 73 to 82\% HRmax, RPE 12 to 14; and Zone 3, high intensity: between 96 and $120 \%$ of VT2, 83 to $97 \%$ HRmax, RPE 15 to 18 [19]. Participants trained 4 to 6 sessions per week with a distribution of $75-80 \%$ in Zone $1, \sim 5 \%$ in Zone 2 , and $15-20 \%$ in Zone 3. Participants controlled their training intensity by continuous HR registration and RPE producing during all training sessions. HR and RPE data files were checked weekly and used to quantify training intensity. In addition participants were required to complete a training diary, recording average HR, training mode, and duration and distance of training sessions throughout the study. Training intensity distribution was quantified from heart rate and RPE to determine the percentage of training time spent in each of the three training zones for every individual training session. The average training time in each zone for all sessions was then determined. All the participants performed their training during the afternoon (12 to $6: 00 \mathrm{pm})$.

\section{Dietary Supplementation and Control of the Intervention Compliance}


The three supplements under investigation were presented as $20 \mathrm{~g}$ sachets of vanilla-flavored powder diluted in $\sim 300 \mathrm{~mL}$ of plain water for each intake. The diluted drinks were similar in appearance, texture and taste, and were isoenergetic. The nutritional composition of each product and the amino acid profile of beef and whey proteins are shown in Table 1. Totaling 70 intakes, supplements were taken once a day for 10 weeks. On training days, supplements were ingested just after the training, whereas on non-training days before breakfast, supplements were selfadministered in the morning.

\section{Table 1}

After completing the first assessment session, each participant was given a batch of one of the three products, assigned according to randomization.

Tolerance, collected from any adverse events and compliance with supplement intake (determined by an individual follow-up) was evaluated continuously during the intervention. Only participants who completed the 70 days of supplementation intake with a minimum training frequency of 4 sessions per week (40 workouts in total) were included in the analysis. Due to nonstudy related reasons, six participants ( 2 per group) dropped from the study. Consequently 24 participants, 8 per group successfully completed the study. Participants verbally confirmed that they maintained their habitual diet throughout the trial period

\section{Statistical Analysis}

A descriptive analysis was performed and subsequently the Kolmogorov-Smirnov and Shapiro-Wilk test were applied to assess normality. Sample characteristics at baseline were compared between conditions (Beef vs. Whey vs. CHO) using one-way Analysis of Variance (ANOVA). Change in performance, body composition, muscle thickness, and blood indices were assessed using $3 \times 2$ repeated measures ANOVA, to compare the effect of supplement conditions (Beef vs. Whey vs. $\mathrm{CHO}$ ) over time (pre vs. post). When interaction between conditions and time was significant, in order to adjust for possible differences at enrollment, percentage of change was analyzed using Analysis of Covariance using first assessment (pre) as covariate. Bonferroni- 
adjusted post-hoc analyses were performed when appropriate. Generalized eta squared $\left(\eta_{G}^{2}\right)$ and Cohen's $d$ values were reported to provide an estimate of standardized effect size (small $\mathrm{d}=0.2$, $\eta_{G}^{2}=0.01 ;$ moderate $\mathrm{d}=0.5, \eta_{G}^{2}=0.06$; and large $\left.\mathrm{d}=0.8, \eta_{G}^{2}=0.14\right)$. Significance level was set to $\mathrm{p}<0.05$. Results are reported as mean (standard deviation) unless stated otherwise. Data analyses were performed with Stata 13.1 (StataCorp, College Station, TX).

\section{RESULTS}

Table 2 shows the dietary monitoring results, presented as the average daily consumption of carbohydrate, protein, fat $\left(\mathrm{gkg}^{-1} \cdot \mathrm{d}^{-1}\right)$, energy $\left(\mathrm{kcal} \mathrm{kg}^{-1} \cdot \mathrm{d}^{-1}\right)$, total iron $\left(\mathrm{mg}^{\cdot-1}\right)$, heme-iron $\left(\mathrm{mg}^{-1}\right)$, and non-heme iron $\left(\mathrm{mgd}^{-1}\right)$ intake, before and after the intervention for the three treatment conditions.

\section{Table 2}

At baseline, no between-groups differences were observed in dietary variables. However, as a result of the nutritional intervention, the Beef group due to a significant increase in total iron intake $(p=0.001)$ increased the intake of heme-iron $(p=0.009)$. Furthermore, the two protein treatment conditions (Beef and Whey) significantly increased the protein intake $(p=0.001)$ while only the $\mathrm{CHO}$ group increased the consumption of carbohydrates $(\mathrm{p}=0.005)$. Additionally, only the CHO $(p=0.008)$ and the Whey $(p=0.021)$ groups, but not the Beef group, produced significant increases in total energy intake. Despite the aforementioned changes from the baseline intakes, no between-treatment differences were observed at post-intervention. No complaints about any negative symptoms (i.e. hypoglycemic reaction) or gastric related discomfort due to the ingestion of supplement during training and non-training days were reported.

At baseline, body composition and $\dot{V} \mathrm{O}_{2 \text { peak }}$ performance was equal between the groups. No significant differences were observed in all variables at test 1 (i.e. prior to study). Pre and post values of body composition, muscle thickness, and $\dot{V} \mathrm{O}_{2 \text { peak }}$ values are provided in Table 3 , and blood variables are presented in Table 4.

\section{Tables 3 and 4}


Main time effects were observed for body mass $(\mathrm{kg})$, fat mass $(\mathrm{kg})$, fat mass $(\%)$, fat-free mass $(\mathrm{kg})$, and fat-free mass $(\%)$. No interaction or between-groups effects were identified. Pairwise comparison revealed a significant reduction in body mass $(\mathrm{p}=0.021)$ for the Beef group (Table 3 ). Significant interaction effects between supplement and time were found in vastus medialis thickness (Table 3) and ferritin concentrations (Table 4). ANCOVA analysis revealed no significant time effects for vastus medialis thickness $\mathrm{F}(2,18)=2.05, \mathrm{p}=0.158, \eta_{G}^{2}=0.116$ but a significant increase in ferritin concentrations $\mathrm{F}(2,18)=20.78, \mathrm{p}<0.001, \eta_{G}^{2}=0.361$. Adjusted marginal means of the differences for each group were $4.55(\mathrm{p}=0.041),-1.54(\mathrm{p}=0.515)$, and $-4.95(\mathrm{p}=0.021)$ for Beef, Whey and $\mathrm{CHO}$ groups respectively. However, no significant post hoc differences between groups were found.

Post-hoc analysis revealed that the Beef condition produced a higher ferritin concentration increase than Whey $(\mathrm{p}<0.001)$ and CHO $(p=0.025)$, and no differences were found between Whey and $\mathrm{CHO}(\mathrm{p}=0.223)$ in this variable. No further differences were observed.

\section{DISCUSSION}

The present study demonstrates that the ingestion of $20 \mathrm{~g}$ of hydrolyzed beef protein over 10 weeks preserved thigh muscle mass in master endurance athletes. Additionally, the ingestion of hydrolyzed beef protein resulted in an increase in serum ferritin levels, which reached similar values observed in the whey and CHO groups, which showed no changes after the intervention. No variation in performance or any of the measured blood parameters were observed for the three analyzed conditions. The decrease in body mass in the Beef group is mainly due to a higher proportion of fat mass loss alongside a minor decrease of the fat-free mass. Furthermore, only the Beef group showed no decrease in vastus medialis thickness, which reinforces the potential positive effect of this supplement to preserve muscle mass in endurance athletes (Burke, 2012). Excessive decrease in muscle mass should be avoided in endurance master athletes as it can compromise performance [22]. As the capacity to elevate the post workout muscle protein synthesis to support recovery process decreases with age [23], the ingestion of a post-workout meal containing between 
$0.25 \mathrm{~g}$ toward $0.4 \mathrm{~g} \mathrm{~kg}$ of high quality protein has been proposed [5], participants allocated in Whey and Beef were ingesting $\sim 0.22 \mathrm{~g} k \mathrm{~kg}$ immediately after exercise. The administered amount would be considered not enough to facilitate muscle repair and remodeling for the current participants [5] and therefore limiting the potential benefit of the used supplement on the muscular recovery process. Additionally, regular physical active individuals are recommended to daily ingest more than 1.2 $\mathrm{gkg}^{-1} \cdot \mathrm{d}^{-1}$ of proteins [13]. According to the diet records, 5 participants (1 in the B, 2 in the Whey and 2 in the $\mathrm{CHO}$, group) were ingesting less than $1.2 \mathrm{~g} \mathrm{~kg}^{-1} \mathrm{~d}^{-1}$ with the remaining participants consuming more than $1.2 \mathrm{gkg}^{-1} \cdot \mathrm{d}^{-1}$ and only 9 participants $(3$ in the $\mathrm{B}, 4$ in the Whey and 2 in the $\mathrm{CHO}$ group) reached the recently average requirement $\left(1.65 \mathrm{~g} \cdot \mathrm{kg}^{-1}\right)$ or recommended protein intake $\left(1.83 \mathrm{~g} \mathrm{~kg}^{-1} \cdot \mathrm{d}^{-1}\right)$ needed to satisfy the metabolic demands of endurance athletes [24]. Furthermore the relative lower amounts of $\mathrm{CHO}$ consumed by the three groups $\sim 3.5 \mathrm{~g} \mathrm{~kg}^{-1} \cdot \mathrm{d}^{-1}$ (Table 2) falls notably below the recommended dose of 5 to $7 \mathrm{~g}$ for endurance athletes [13], which can negatively influence the loss of body mass as well as targeted performance changes.

Although there is no exact agreement on serum ferritin levels associated with iron depletion/deficiency, with various suggestions ranging from $<10$ to $<35 \mathrm{ng} / \mathrm{mL}$ [13], for the present study, iron deficiency was considered as a serum ferritin concentration of $<15 \mathrm{ng} / \mathrm{ml}$, and anemia was defined as a hemoglobin concentration of $<13 \mathrm{~g} / \mathrm{dl}$ [25]. Even though at baseline or postintervention, none of the participants were iron deficient or anemic (Table 4), only the Beef group demonstrated a post intervention significant increase of serum ferritin concentrations. However, at baseline participants included in the Beef group had non-significant $(F(2,21)=0.479, p=0.626)$ lowers levels of ferritin concentrations compared to the participants in the other groups. After the 10-week intervention participants in the Beef group reached similar ferritin levels as observed in the Whey and $\mathrm{CHO}$ groups. Iron intake for all groups before and during the intervention was notably above the recommended dosage for males endurance athletes $\left(>8 \mathrm{mgd}^{-1}\right)$ [13]. Nonetheless only the Beef group demonstrated a significant increase of total and heme iron dietary intakes. Indeed the individual analysis demonstrated that all participants in the Beef group increased their dietary heme 
iron ingestion and also serum ferritin concentrations, whilst only 3 participants in the Whey group, and 1 participant in the $\mathrm{CHO}$ group, demonstrated a trend of increasing serum ferritin concentration during the intervention (complementary material). Additionally, two participants in the Beef treatment group showed low initial ferritin values $(20.3$ and $24.9 \mathrm{ng} / \mathrm{mL})$, but still within normal ranges, whilst regardless of group no other participants demonstrated baseline values below 50 $\mathrm{ng} / \mathrm{mL}$. As the absorption of dietary iron is increased with a compromised iron status [26] a markedly improved hematological index was expected in participants with very low baseline iron values. However, regardless of initial iron status all the participants in the Beef group showed similar changes in ferritin concentrations.

Because the participants were trained endurance athletes with all the hematological parameters within the normal ranges [27] their, body composition, $\dot{V} \mathrm{O}_{2 \text { peak }}$ performance, and the majority of the blood markers may lack significant change as an effect of the dietary supplementation. Due to its long-term consistency and maintenance with a regular training program [28], the metabolism of iron and protein, body composition, and performance are well-established in this population. This may further explain the lack of any changes in performance and the measured blood markers with the exception of the ferritin levels. The present investigation is novel as the supplementation effects was completed in masters endurance athletes during the season, where individuals performed their regular training program integrated in their lifestyle routines. Despite the aforementioned concerns about a low carbohydrate dietary intake at baseline participants where apparently well nourished and relatively well trained.

The convenience of additional iron intake in the form of hydrolyzed beef protein powder suggests that it may be a suitable alternative in the prevention of iron depletion through maintenance of iron stores during training periods in male endurance athletes. There was no significant difference between groups as an effect of the intervention in energy intake, but as highlighted, Beef was the only group that increased the total iron and specifically the heme-iron intake. 
Further research using larger groups of participants is required to confirm if dietary interventions through a dietary change can significantly improve iron status and its potential impact on exercise performance. Nevertheless, considering the research design and sample size limitations, the current findings demonstrate the effects of hydrolyzed beef protein supplementation in preserving lower limb muscle mass and in improving the iron status. The lower levels of serum ferritin at the beginning of the study observed in the beef group does not permit further conclusion about the potential benefits of ingesting hydrolyzed beef protein powder for maintaining or increasing iron storage in endurance athletes.

\section{FUNDING}

Funding Crown Sports Nutrition and the University of Greenwich provided joint funding for the completion of this project; however, this does not affect this original research content and purpose.

Conflict of interest: The authors declare that they have no conflicts of interest relevant to the content of this manuscript.

\section{ACKNOWLEDGEMENTS:}

The study was designed by FN and EL. Data were collected by MS and FN. EL, NA and FN analyzed the data. Interpretation and manuscript preparation were undertaken by all authors (FN, EL, BN, BK, TC, MS and NA). All authors approved the final version of the paper.

The authors thank, Kelly Cooper, Julia Stent, Carmen Dina Harmse, Alexandros, Anagnostou, Carlo Poggiali and Richard Jeffrey for their help and support during the data collection. 


\section{References}

1. Burke DE, Johnson JV, Vukovich MD, Kattelmann KK. Effects of lean beef supplementation on iron status, body composition and performance of collegiate distance runners Food and Nutrition Sciences 3:810, 2012.

2. Telford RD, Sly GJ, Hahn AG, Cunningham RB, Bryant C, Smith JA. Footstrike is the major cause of hemolysis during running. J Appl Physiol (1985). 94:38-42, 2003.

3. Beard J, Tobin B. Iron status and exercise. Am J Clin Nutr. 72:594S-7S, 2000.

4. Alaunyte I, Stojceska V, Plunkett A. Iron and the female athlete: a review of dietary treatment methods for improving iron status and exercise performance. J Int Soc Sports Nutr. 12:38, 2015.

5. Doering TM, Reaburn PR, Phillips SM, Jenkins DG. Postexercise Dietary Protein Strategies to Maximize Skeletal Muscle Repair and Remodeling in Masters Endurance Athletes: A Review. Int J Sport Nutr Exerc Metab. 26:168-78, 2016.

6. Hausswirth C, Le Meur Y. Physiological and nutritional aspects of post-exercise recovery: specific recommendations for female athletes. Sports Med. 41:861-82, 2011.

7. Easthope CS, Hausswirth C, Louis J, Lepers R, Vercruyssen F, Brisswalter J. Effects of a trail running competition on muscular performance and efficiency in well-trained young and master athletes. Eur J Appl Physiol. 110:1107-16, 2010.

8. Naclerio F, Larumbe-Zabala E, Cooper R, Jimenez A, Goss-Sampson M. Effect of a carbohydrate-protein multi-ingredient supplement on intermittent sprint performance and muscle damage in recreational athletes. Appl Physiol Nutr Metab. 39:1151-8, 2014.

9. Cruzat VF, Krause M, Newsholme P. Amino acid supplementation and impact on immune function in the context of exercise. J Int Soc Sports Nutr. 11:61, 2014.

10. Chernoff R. Protein and older adults. J Am Coll Nutr. 23:627S-30S, 2004. 
11. Naclerio F, Larumbe-Zabala E. Effects of Whey Protein Alone or as Part of a Multiingredient Formulation on Strength, Fat-Free Mass, or Lean Body Mass in Resistance-Trained Individuals: A Meta-analysis. Sports Med. 46:125-37, 2016.

12. Phillips SM. Nutrient-rich meat proteins in offsetting age-related muscle loss. Meat Sci. 92:174-8, 2012.

13. Thomas DT, Erdman KA, Burke LM. Position of the Academy of Nutrition and Dietetics, Dietitians of Canada, and the American College of Sports Medicine: Nutrition and Athletic Performance. J Acad Nutr Diet. 116:501-28, 2016.

14. Ross WD, Marflel-Jones MJ. Kineanthropometry. In: MacDougal JC, Wenger HA, Green HJ, editors. Physiological Testing of High Performance Athlete. Champaign, IL: Human Kinetics, pp 223-308 1991.

15. Dempster P, Aitkens S. A new air displacement method for the determination of human body composition. Med Sci Sports Exerc. 27:1692-7, 1995.

16. Siri WE. Body composition from fluid spaces and density: analysis of methods. In: Brozek J, Henschel A, Washington DC, editors. Techniques for measuring body composition: National Academeny of Sciences, National Research Council pp 223-44 1961.

17. Karsten B, Jobson SA, Hopker J, Stevens L, Beedie C. Validity and reliability of critical power field testing. Eur J Appl Physiol. 115:197-204, 2015.

18. Bradley M, O’Donnell P. Atlas of musculoskeletal ultrasound anatomy London Greenwich Medical Media 2002

19. Esteve-Lanao J, Foster C, Seiler S, Lucia A. Impact of training intensity distribution on performance in endurance athletes. J Strength Cond Res. 21:943-9, 2007.

20. Borg GA. Psychophysical bases of perceived exertion. Med Sci Sports Exerc. 14:377-81, 1982.

21. Miller PE, Alexander DD, Perez V. Effects of whey protein and resistance exercise on body composition: a meta-analysis of randomized controlled trials. J Am Coll Nutr. 33:163-75, 2014. 
22. Reaburn P, Dascombe B. Endurance performance in masters athletes. Eur Rev Aging Phys Act. 5:31-42, 2008.

23. Durham WJ, Casperson SL, Dillon EL, Keske MA, Paddon-Jones D, Sanford AP, et al. Agerelated anabolic resistance after endurance-type exercise in healthy humans. FASEB J. 24:4117-27, 2010.

24. Kato H, Suzuki K, Bannai M, Moore DR. Protein Requirements Are Elevated in Endurance Athletes after Exercise as Determined by the Indicator Amino Acid Oxidation Method. PLoS One. 11:e0157406, 2016.

25. Johnson J, Burke D, Vukovich M, Kattelmann K. The effects of lean beef supplementation on the iron status of college athletes. Nutrition and Dietary Supplements 4:39-45, 2012.

26. Beard J, Han O. Systemic iron status. Biochim Biophys Acta. 1790:584-8, 2009.

27. Pichon AP, Connes P, Robach P. Effects of acute and chronic hematocrit modulations on blood viscosity in endurance athletes. Clin Hemorheol Microcirc. 64:115-23, 2016.

28. Burrows M, Bird S. The physiology of the highly trained female endurance runner. Sports Med. 30:281-300, 2000. 


\section{Figures}

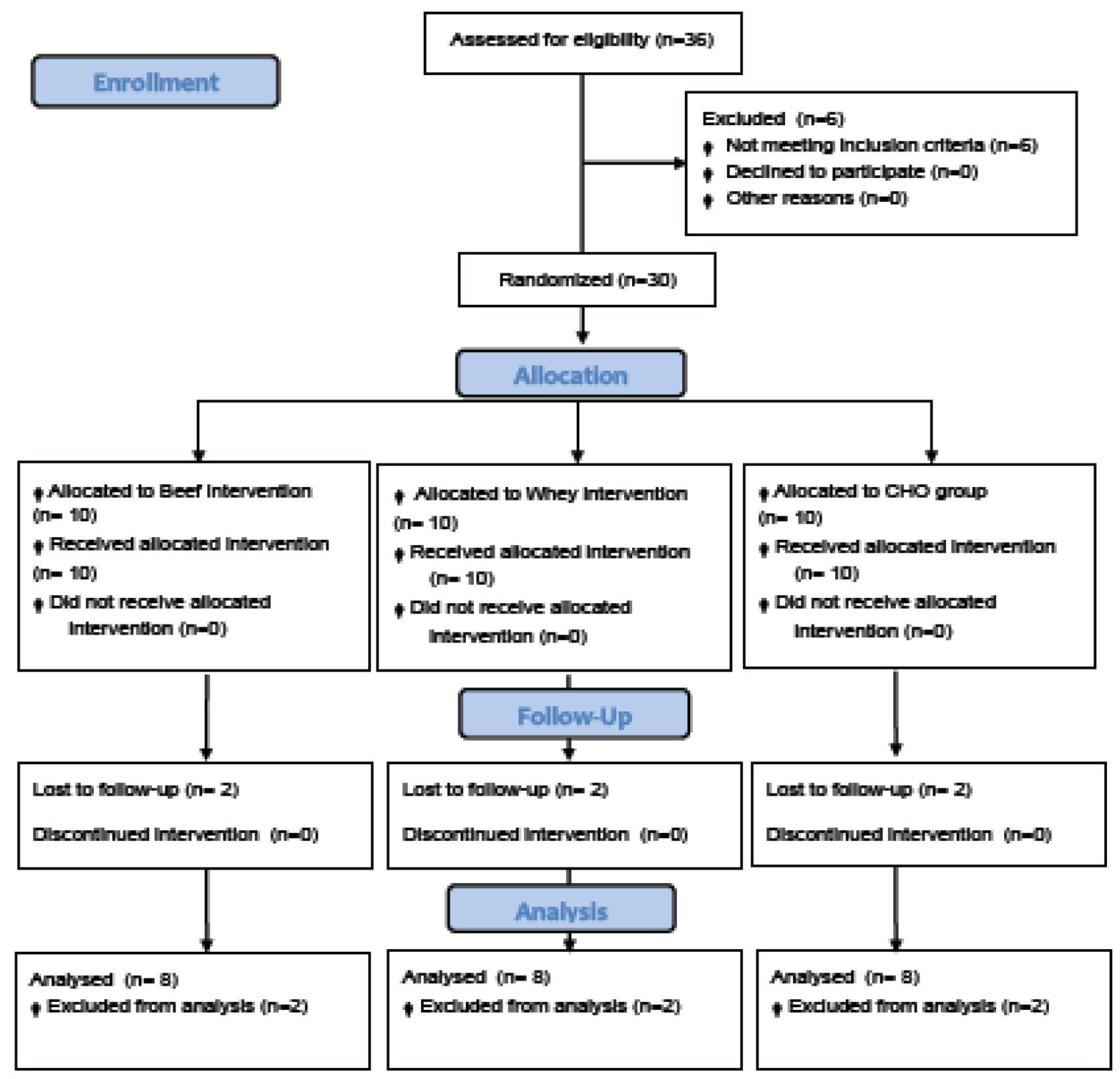

Figure 1: Flow diagram of participants throughout the course of the study 
Complementary Material

Serum Ferritin Concentrations Individuals Responses by Group (absolute values)

Beef $(n=8)$
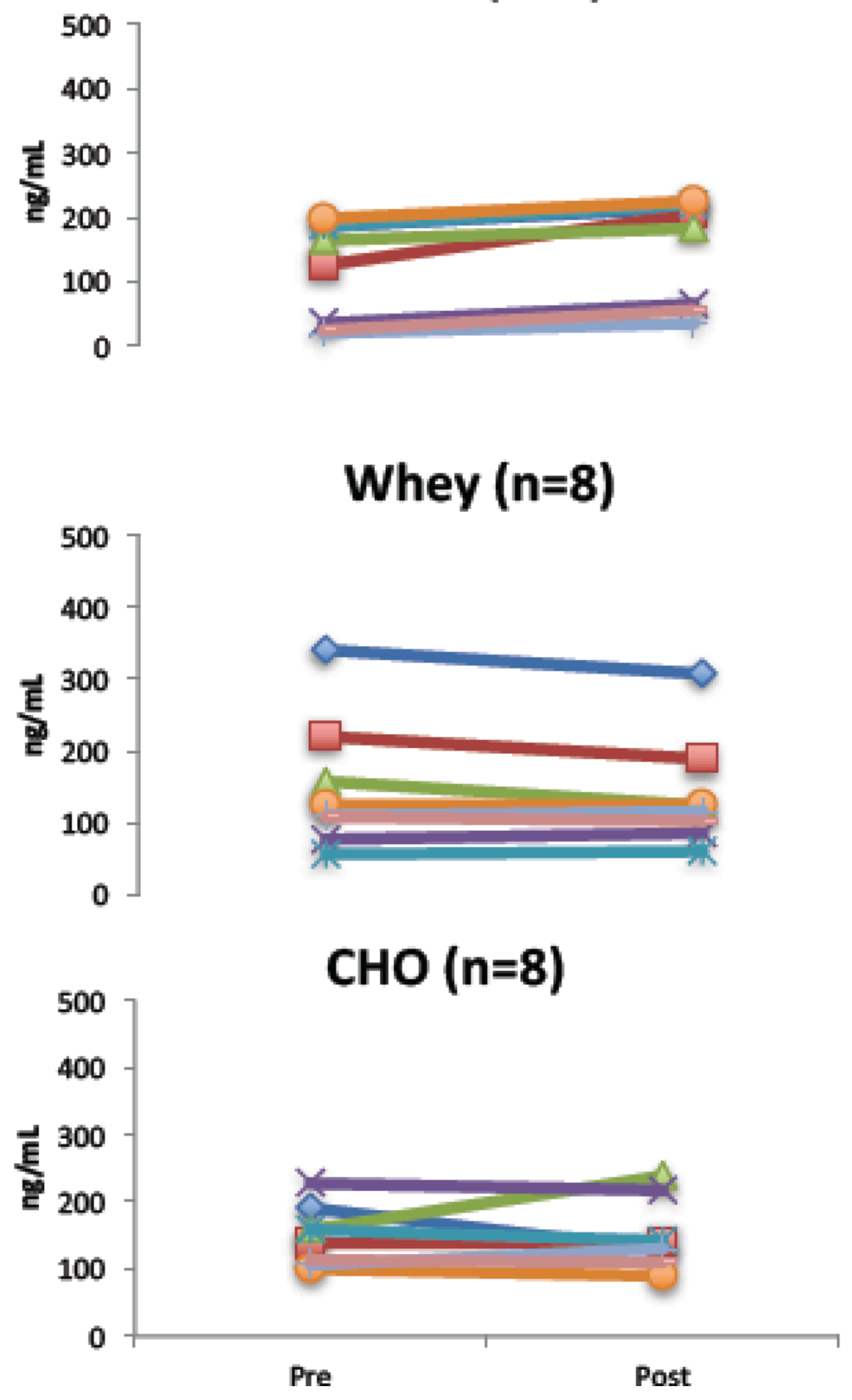


\section{Tables}

Table 1.

Nutritional composition of drinks per intake ( $20 \mathrm{~g}$ of powder plus $\sim 300 \mathrm{ml}$ of plain water)

\begin{tabular}{|c|c|c|c|}
\hline Nutrient & Beef & Whey & $\mathrm{CHO}$ \\
\hline Energy value (kcal) & 82 & 78 & 82 \\
\hline Carbohydrates (g) & 0 & 0 & 20 \\
\hline Lipids (g) & 1.54 & 0.3 & 0 \\
\hline Proteins $(\mathrm{g})$ & 16.4 & 18 & 0 \\
\hline Alanine & 1.04 & 1.06 & - \\
\hline Arginine & 1.06 & 0.38 & - \\
\hline Aspartic acid & 1.50 & 2.29 & - \\
\hline Cysteine & 0.16 & 0.48 & - \\
\hline Glutamic acid & 2.58 & 3.34 & - \\
\hline Glycine & 1.07 & 0.34 & - \\
\hline Histidine & 0.55 & 0.31 & - \\
\hline Isoleucine & 0.75 & 1.00 & - \\
\hline Leucine & 1.32 & 1.93 & - \\
\hline Lysine & 1.44 & 1.81 & - \\
\hline Methionine & 0.39 & 0.44 & - \\
\hline Phenylalanine & 0.65 & 0.61 & - \\
\hline Proline & 0.81 & 1.17 & - \\
\hline Serine & 0.65 & 1.05 & - \\
\hline Threonine & 0.73 & 1.44 & - \\
\hline Tryptophan & 0.187 & 0.39 & - \\
\hline Tyrosine & 0.52 & 5.57 & - \\
\hline Valine & 0.80 & 0.98 & - \\
\hline Total EEA & 6.82 & 8.91 & - \\
\hline Heme Iron (mg) & 16.27 & - & - \\
\hline Zinc (mg) & 19.05 & - & - \\
\hline Folic Acid $(\mu \mathrm{g})$ & 84.71 & - & - \\
\hline Vitamin B $12(\mu \mathrm{g})$ & 3.26 & - & - \\
\hline
\end{tabular}

Notes: EEA, essential amino acids; $\mathrm{CHO}$, Carbohydrates 
Table 2. Descriptive analysis of the participants' diet composition.

\begin{tabular}{|c|c|c|c|c|c|c|c|c|c|c|c|c|c|c|}
\hline \multirow[t]{2}{*}{ Treatment } & \multicolumn{2}{|c|}{$\begin{array}{l}\text { Total Iron } \\
\left(\mathrm{mgd}^{-1}\right)\end{array}$} & \multicolumn{2}{|c|}{$\begin{array}{l}\text { Non-heme Iron } \\
\quad\left(\mathrm{mg} \mathrm{d}^{-1}\right)\end{array}$} & \multicolumn{2}{|c|}{$\begin{array}{l}\text { Heme-Iron } \\
\left(\mathrm{mgd} \mathrm{d}^{-1}\right)\end{array}$} & \multicolumn{2}{|c|}{$\begin{array}{l}\text { Proteins } \\
\left(\mathrm{gkg}^{-1} \cdot \mathrm{d}^{-1}\right)\end{array}$} & \multicolumn{2}{|c|}{$\begin{array}{l}\text { Carbohydrate } \\
\left(\mathrm{g} \mathrm{kg}^{-1} \mathrm{~d}^{-1}\right)\end{array}$} & \multicolumn{2}{|c|}{$\begin{array}{c}\text { Fats } \\
\left(\mathrm{gkg}^{-1} \mathrm{~d}^{-1}\right)\end{array}$} & \multicolumn{2}{|c|}{$\begin{array}{c}\text { Energy } \\
\left(\mathrm{kcalkg}^{-1} \cdot \mathrm{d}^{-1}\right)\end{array}$} \\
\hline & pre & post & Pre & post & Pre & post & Pre & Post & pre & Post & pre & post & pre & post \\
\hline Beef $(n=8)$ & $\begin{array}{l}11.83 \\
(3.84)\end{array}$ & $\begin{array}{c}14.56 * * \\
(3.96)\end{array}$ & $\begin{array}{c}8.09 \\
(3.47)\end{array}$ & $\begin{array}{c}8.43 \\
(3.37)\end{array}$ & $\begin{array}{c}3.74 \\
(2.14)\end{array}$ & $\begin{array}{l}5.70^{* *} \\
(1.21)\end{array}$ & $\begin{array}{c}1.29 \\
(0.25)\end{array}$ & $\begin{array}{l}1.52 * * \\
(0.24)\end{array}$ & $\begin{array}{c}3.36 \\
(1.21)\end{array}$ & $\begin{array}{c}3.46 \\
(1.14)\end{array}$ & $\begin{array}{c}1.07 \\
(0.26)\end{array}$ & $\begin{array}{c}1.09 \\
(0.26)\end{array}$ & $\begin{array}{l}28.58 \\
(4.40)\end{array}$ & $\begin{array}{l}30.54 \\
(4.17)\end{array}$ \\
\hline Whey $(\mathrm{n}=8)$ & $\begin{array}{l}15.02 \\
(8.97)\end{array}$ & $\begin{array}{l}15.72 \\
(8.37)\end{array}$ & $\begin{array}{l}11.66 \\
(6.55)\end{array}$ & $\begin{array}{l}11.65 \\
(7.75)\end{array}$ & $\begin{array}{c}3.36 \\
(3.03)\end{array}$ & $\begin{array}{c}4.07 \\
(2.02)\end{array}$ & $\begin{array}{c}1.48 \\
(0.64)\end{array}$ & $\begin{array}{l}1.72 * * \\
(0.65)\end{array}$ & $\begin{array}{c}3.53 \\
(1.58)\end{array}$ & $\begin{array}{c}3.68 \\
(1.47)\end{array}$ & $\begin{array}{c}1.39 \\
(0.38)\end{array}$ & $\begin{array}{c}1.40 \\
(0.38)\end{array}$ & $\begin{array}{l}30.34 \\
(7.93)\end{array}$ & $\begin{array}{l}35.10^{*} \\
(9.68)\end{array}$ \\
\hline $\mathrm{CHO}(\mathrm{n}=8)$ & $\begin{array}{l}14.03 \\
(3.42)\end{array}$ & $\begin{array}{l}15.21 \\
(4.39)\end{array}$ & $\begin{array}{l}10.36 \\
(3.31)\end{array}$ & $\begin{array}{l}10.40 \\
(3.25)\end{array}$ & $\begin{array}{c}3.67 \\
(2.74)\end{array}$ & $\begin{array}{c}4.85 \\
(2.58)\end{array}$ & $\begin{array}{c}1.30 \\
(0.24)\end{array}$ & $\begin{array}{c}1.40 \\
(0.25)\end{array}$ & $\begin{array}{c}2.98 \\
(1.18)\end{array}$ & $\begin{array}{l}3.23 * * \\
(1.19)\end{array}$ & $\begin{array}{c}1.35 \\
(0.80)\end{array}$ & $\begin{array}{c}1.34 \\
(0.60)\end{array}$ & $\begin{array}{l}25.84 \\
(7.97)\end{array}$ & $\begin{array}{c}31.44^{* *} \\
(9.28)\end{array}$ \\
\hline
\end{tabular}

Notes: Pre and post intervention values are presented as mean (standard deviation)

${ }^{*} \mathrm{p}<0.05$ and $* * \mathrm{p}<0.01$ from pre to post-intervention (last week of intervention)

Table 3. Descriptive analysis of the body composition, muscle thickness and endurance performance variables

\begin{tabular}{|c|c|c|c|c|c|c|c|}
\hline \multirow{2}{*}{ Variables } & \multicolumn{2}{|c|}{ Beef $(n=8)$} & \multicolumn{2}{|c|}{ Whey $(n=8)$} & \multicolumn{2}{|c|}{$\mathrm{CHO}(\mathrm{n}=8)$} & \multirow{2}{*}{$\begin{array}{l}\text { Repeated Measure ANOVA } \\
\text { (3 groups x } 2 \text { times) }\end{array}$} \\
\hline & Pre & Post & Pre & Post & Pre & Post & \\
\hline Body mass (Kg) & $\begin{array}{l}78.9 \\
(9.5)\end{array}$ & $\begin{array}{c}77.3 \\
(8.8)^{*}\end{array}$ & $\begin{array}{c}85.1 \\
(11.6)\end{array}$ & $\begin{array}{c}84.7 \\
(13.5)\end{array}$ & $\begin{array}{l}80.2 \\
(7.1)\end{array}$ & $\begin{array}{l}79.4 \\
(6.4)\end{array}$ & $\begin{array}{l}\text { Time: } \mathrm{F}(1,21)=6.19, \mathrm{p}=0.021, \eta_{G}^{2}=0.003 \\
\text { Group: } \mathrm{F}(2,21)=1.05, \mathrm{p}=0.367, \eta_{G}^{2}=0.09 \\
\text { Group } \mathrm{x} \text { Time: } \mathrm{F}(2,21)=0.9, \mathrm{p}=0.423, \eta_{G}^{2}=0.001\end{array}$ \\
\hline Fat mass $(\mathrm{kg})$ & $\begin{array}{l}14.9 \\
(3.9)\end{array}$ & $\begin{array}{l}13.9 \\
(4.7)\end{array}$ & $\begin{array}{l}19.7 \\
(8.4)\end{array}$ & $\begin{array}{l}18.9 \\
(10)\end{array}$ & $\begin{array}{l}15.4 \\
(4.9)\end{array}$ & $\begin{array}{l}14.8 \\
(5.0)\end{array}$ & $\begin{array}{l}\text { Time: } \mathrm{F}(1,21)=4.75, \mathrm{p}=0.041, \eta_{G}^{2}=0.004 \\
\text { Group: } \mathrm{F}(2,21)=1.35, \mathrm{p}=0.282, \eta_{G}^{2}=0.112 \\
\text { Group } \mathrm{x} \text { Time: } \mathrm{F}(2,21)=0.11, \mathrm{p}=0.895, \eta_{G}^{2}=0\end{array}$ \\
\hline Fat mass $(\%)$ & $\begin{array}{l}18.9 \\
(4.2)\end{array}$ & $\begin{array}{l}17.9 \\
(5.2)\end{array}$ & $\begin{array}{l}22.5 \\
(7.7)\end{array}$ & $\begin{array}{l}21.4 \\
(9.1)\end{array}$ & $\begin{array}{l}19.2 \\
(5.5)\end{array}$ & $\begin{array}{l}18.4 \\
(5.8)\end{array}$ & $\begin{array}{l}\text { Time: } \mathrm{F}(1,21)=5.55, \mathrm{p}=0.028, \eta_{G}^{2}=0.006 \\
\text { Group: } \mathrm{F}(2,21)=0.75, \mathrm{p}=0.486, \eta_{G}^{2}=0.065 \\
\text { Group x Time: } \mathrm{F}(2,21)=0.07, \mathrm{p}=0.934, \eta_{G}^{2}=0\end{array}$ \\
\hline Fat-free mass (kg) & $\begin{array}{c}64 \\
(7.9)\end{array}$ & $\begin{array}{l}63.4 \\
(7.6)\end{array}$ & $\begin{array}{l}65.4 \\
(6.1)\end{array}$ & $\begin{array}{l}65.8 \\
(6.8)\end{array}$ & $\begin{array}{l}64.7 \\
(5.9)\end{array}$ & $\begin{array}{l}64.7 \\
(5.5)\end{array}$ & $\begin{array}{l}\text { Time: } \mathrm{F}(1,21)=0.25, \mathrm{p}=0.622, \eta_{G}^{2}=0 \\
\text { Group: } \mathrm{F}(2,21)=0.16, \mathrm{p}=0.853, \eta_{G}^{2}=0.015 \\
\text { Group x Time: } \mathrm{F}(2,21)=2.12, \mathrm{p}=0.145, \eta_{G}^{2}=0.001\end{array}$ \\
\hline Fat-free mass (\%) & $\begin{array}{l}81.1 \\
(4.2)\end{array}$ & $\begin{array}{l}82.1 \\
(5.2)\end{array}$ & $\begin{array}{l}77.5 \\
(7.7)\end{array}$ & $\begin{array}{l}78.6 \\
(9.1)\end{array}$ & $\begin{array}{l}80.8 \\
(5.5)\end{array}$ & $\begin{array}{l}81.6 \\
(5.8)\end{array}$ & $\begin{array}{l}\text { Time: } \mathrm{F}(1,21)=5.55, \mathrm{p}=0.028, \eta_{G}^{2}=0.006 \\
\text { Group: } \mathrm{F}(2,21)=0.75, \mathrm{p}=0.486, \eta_{G}^{2}=0.065 \\
\text { Group x Time: } \mathrm{F}(2,21)=0.07, \mathrm{p}=0.934, \eta_{G}^{2}=0\end{array}$ \\
\hline Vastus medialis thickness (mm) & $\begin{array}{l}34.1 \\
(6.1)\end{array}$ & $\begin{array}{l}35.5 \\
(7.4)\end{array}$ & $\begin{array}{l}38.4 \\
(3.8)\end{array}$ & $\begin{array}{c}36.9 * \\
(2.8)\end{array}$ & $\begin{array}{l}36.0 \\
(4.8)\end{array}$ & $\begin{array}{c}34.1 * \\
(4.4)\end{array}$ & $\begin{array}{l}\text { Time: } \mathrm{F}(1,21)=2.49, \mathrm{p}=0.129, \eta_{G}^{2}=0.005 \\
\text { Group: } \mathrm{F}(2,21)=0.8, \mathrm{p}=0.461, \eta_{G}^{2}=0.068 \\
\text { Group x Time: } \mathrm{F}(2,21)=5.78, \mathrm{p}=0.010, \eta_{G}^{2}=0.023\end{array}$ \\
\hline Vo2peak (ml/kg/min) & $\begin{array}{c}48 \\
(6.4)\end{array}$ & $\begin{array}{l}46.4 \\
(6.8)\end{array}$ & $\begin{array}{c}45 \\
(7.6)\end{array}$ & $\begin{array}{l}46.8 \\
(8.6)\end{array}$ & $\begin{array}{l}50.9 \\
(6.1)\end{array}$ & $\begin{array}{l}48.9 \\
(6.3)\end{array}$ & $\begin{array}{l}\text { Time: } \mathrm{F}(1,21)=0.69, \mathrm{p}=0.416, \eta_{G}^{2}=0.002 \\
\text { Group: } \mathrm{F}(2,21)=0.72, \mathrm{p}=0.496, \eta_{G}^{2}=0.061 \\
\text { Group x Time: } \mathrm{F}(2,21)=2.76, \mathrm{p}=0.086, \eta_{G}^{2}=0.016\end{array}$ \\
\hline
\end{tabular}

Note: Pre and post intervention values are presented as mean (standard deviation)

${ }^{*} \mathrm{p}<0.05$ respect to pre intervention values 
Table 4. Descriptive analysis of the hematological variables

\begin{tabular}{|c|c|c|c|c|c|c|c|}
\hline \multirow{2}{*}{ Variables } & \multicolumn{2}{|c|}{ Beef $(n=8)$} & \multicolumn{2}{|c|}{ Whey $(\mathrm{n}=8)$} & \multicolumn{2}{|c|}{$\mathrm{CHO}(\mathrm{n}=8)$} & \multirow{2}{*}{$\begin{array}{c}\text { Repeated Measure ANOVA } \\
(3 \text { groups x } 2 \text { times })\end{array}$} \\
\hline & Pre & Post & Pre & Post & Pre & Post & \\
\hline Red blood cells $\left(10^{6} / \mathrm{mm}^{3}\right)$ & $\begin{array}{l}4.8 \\
(0.4)\end{array}$ & $\begin{array}{c}4.8 \\
(0.3)\end{array}$ & $\begin{array}{c}5 \\
(0.3)\end{array}$ & $\begin{array}{c}4.9 \\
(0.3)\end{array}$ & $\begin{array}{l}4.8 \\
(0.4)\end{array}$ & $\begin{array}{c}4.8 \\
(0.3)\end{array}$ & $\begin{array}{l}\text { Time: } \mathrm{F}(1,21)=0.07, \mathrm{p}=0.794, \eta_{G}^{2}=0.001 \\
\text { Group: } \mathrm{F}(2,21)=1.07, \mathrm{p}=0.363, \eta_{G}^{2}=0.07 \\
\text { Group x Time: } \mathrm{F}(2,21)=0.32, \mathrm{p}=0.733, \eta_{G}^{2}=0.008\end{array}$ \\
\hline Hemoglobin $(\mathrm{g} / \mathrm{dl})$ & $\begin{array}{l}14.8 \\
(0.8)\end{array}$ & $\begin{array}{l}14.8 \\
(1.1)\end{array}$ & $\begin{array}{l}15.3 \\
(1.1)\end{array}$ & $\begin{array}{l}15 \\
(1)\end{array}$ & $\begin{array}{c}14.6 \\
(1)\end{array}$ & $\begin{array}{l}14.8 \\
(1)\end{array}$ & $\begin{array}{l}\text { Time: } \mathrm{F}(1,21)=0.06, \mathrm{p}=0.813, \eta_{G}^{2}=0.001 \\
\text { Group: } \mathrm{F}(2,21)=0.69, \mathrm{p}=0.510, \eta_{G}^{2}=0.048 \\
\text { Group x Time: } \mathrm{F}(2,21)=0.45, \mathrm{p}=0.644, \eta_{G}^{2}=0.01\end{array}$ \\
\hline Hematocrit (\%) & $\begin{array}{l}41.6 \\
(2.6)\end{array}$ & $\begin{array}{l}41.1 \\
(2.8)\end{array}$ & $\begin{array}{r}42.9 \\
(3)\end{array}$ & $\begin{array}{l}41.5 \\
(2.7)\end{array}$ & $\begin{array}{l}40.6 \\
(3.2)\end{array}$ & $\begin{array}{l}40.8 \\
(2.4)\end{array}$ & $\begin{array}{l}\text { Time: } \mathrm{F}(1,21)=1.01, \mathrm{p}=0.327, \eta_{G}^{2}=0.012 \\
\text { Group: } \mathrm{F}(2,21)=0.82, \mathrm{p}=0.455, \eta_{G}^{2}=0.055 \\
\text { Group x Time: } \mathrm{F}(2,21)=0.6, \mathrm{p}=0.556, \eta_{G}^{2}=0.015\end{array}$ \\
\hline $\begin{array}{l}\text { Mean corpuscular volume } \\
\qquad\left(\mathrm{mm}^{3}\right)\end{array}$ & $\begin{array}{l}86.3 \\
(3.2)\end{array}$ & $\begin{array}{l}85.7 \\
(3.8)\end{array}$ & $\begin{array}{l}85.6 \\
(3.1)\end{array}$ & $\begin{array}{l}85.6 \\
(3.5)\end{array}$ & $\begin{array}{l}84.9 \\
(2.7)\end{array}$ & $\begin{array}{l}85.3 \\
(2.9)\end{array}$ & $\begin{array}{l}\text { Time: } \mathrm{F}(1,21)=0.04, \mathrm{p}=0.845, \eta_{G}^{2}=0 \\
\text { Group: } \mathrm{F}(2,21)=0.17, \mathrm{p}=0.845, \eta_{G}^{2}=0.015 \\
\text { Group x Time: } \mathrm{F}(2,21)=0.94, \mathrm{p}=0.407, \eta_{G}^{2}=0.004\end{array}$ \\
\hline $\begin{array}{l}\text { Mean corpuscular } \\
\text { hemoglobin }(\mathrm{pg})\end{array}$ & $\begin{array}{l}30.7 \\
(1.1)\end{array}$ & $\begin{array}{l}30.8 \\
(1.4)\end{array}$ & $\begin{array}{l}30.5 \\
(1.3)\end{array}$ & $\begin{array}{l}30.7 \\
(1.2)\end{array}$ & $\begin{array}{l}30.5 \\
(1.1)\end{array}$ & $\begin{array}{l}30.8 \\
(1.3)\end{array}$ & $\begin{array}{l}\text { Time: } \mathrm{F}(1,21)=2.13, \mathrm{p}=0.159, \eta_{G}^{2}=0.008 \\
\text { Group: } \mathrm{F}(2,21)=0.06, \mathrm{p}=0.947, \eta_{G}^{2}=0.005 \\
\text { Group x Time: } \mathrm{F}(2,21)=0.21, \mathrm{p}=0.812, \eta_{G}^{2}=0.002\end{array}$ \\
\hline $\begin{array}{l}\text { Mean corpuscular hemoglobin } \\
\text { concentration }(\mathrm{g} / \mathrm{dl})\end{array}$ & $\begin{array}{l}35.5 \\
(0.5)\end{array}$ & $\begin{array}{c}36 \\
(0.7)\end{array}$ & $\begin{array}{l}35.7 \\
(0.6)\end{array}$ & $\begin{array}{l}35.9 \\
(0.7)\end{array}$ & $\begin{array}{l}35.9 \\
(0.7)\end{array}$ & $\begin{array}{l}36.2 \\
(0.8)\end{array}$ & $\begin{array}{l}\text { Time: } \mathrm{F}(1,21)=3.81, \mathrm{p}=0.064, \eta_{G}^{2}=0.06 \\
\text { Group: } \mathrm{F}(2,21)=0.69, \mathrm{p}=0.515, \eta_{G}^{2}=0.041 \\
\text { Group x Time: } \mathrm{F}(2,21)=0.39, \mathrm{p}=0.684, \eta_{G}^{2}=0.013\end{array}$ \\
\hline $\begin{array}{l}\text { Red cell distribution } \\
\text { width (\%) }\end{array}$ & $\begin{array}{l}11.3 \\
(0.8)\end{array}$ & $\begin{array}{l}10.8 \\
(1.2)\end{array}$ & $\begin{array}{l}11.2 \\
(0.9)\end{array}$ & $\begin{array}{l}10.2 \\
(1.1)\end{array}$ & $\begin{array}{l}10.8 \\
(1.1)\end{array}$ & $\begin{array}{l}10.8 \\
(0.9)\end{array}$ & $\begin{array}{l}\text { Time: } \mathrm{F}(1,21)=3.57, \mathrm{p}=0.073, \eta_{G}^{2}=0.065 \\
\text { Group: } \mathrm{F}(2,21)=0.47, \mathrm{p}=0.630, \eta_{G}^{2}=0.026 \\
\text { Group x Time: } \mathrm{F}(2,21)=1.14, \mathrm{p}=0.340, \eta_{G}^{2}=0.043\end{array}$ \\
\hline Ferritin $(\mathrm{ng} / \mathrm{mL})$ & $\begin{array}{l}117.5 \\
(78.3)\end{array}$ & $\begin{array}{c}150.5^{*} \\
(82.8)\end{array}$ & $\begin{array}{l}149.1 \\
(92.1)\end{array}$ & $\begin{array}{l}138.5 \\
(77.7)\end{array}$ & $\begin{array}{l}149.0 \\
(41.3)\end{array}$ & $\begin{array}{l}150.0 \\
(48.1)\end{array}$ & $\begin{array}{l}\text { Time: } \mathrm{F}(1,21)=2.55, \mathrm{p}=0.125, \eta_{G}^{2}=0.004 \\
\text { Group: } \mathrm{F}(2,21)=1.6, \mathrm{p}=0.226, \eta_{G}^{2}=0.128 \\
\text { Group } \mathrm{x} \text { Time: } \mathrm{F}(2,21)=4.72, \mathrm{p}=0.020, \eta_{G}^{2}=0.015\end{array}$ \\
\hline
\end{tabular}

Note: Pre and post intervention values are presented as mean (standard deviation). 